\title{
IMPLEMENTASI PROGRAM BIMBINGAN PERKAWINAN PRANIKAH BAGI CALON PENGANTIN DI KUA KECAMATAN CILANDAK KOTA JAKARTA SELATAN
}

\author{
Abdul Jalil \\ Badan Penelitian dan Pengembangan dan Pendidikan dan Pelatihan - Kementerian Agama \\ Email: abduljalil.ruby@gmail.com \\ do) https://doi.org/10.36052/andragogi.v7i2.93
Diterima: 9 Oktober 2019 | Disetujui: 2 Desember 2019 | Dipublikasikan: 30 Desember 2019
}

\begin{abstract}
Abstrak
Tujuan penelitian ini untuk mengetahui bagaimana implementasi program bimbingan perkawinan pranikah bagi calon pengantin di KUA Kecamatan Cilandak Kota Jakarta Selatan. Metode penelitian ini adalah deskripsi dengan pendekatan kualitatif. Analisis data menggunakan logika berpikir di mana silogisme dibangun berdasarkan pada hal-hal khusus dan bermuara pada kesimpulan-kesimpulan umum. Program bimbingan perkawinan pranikah bagi calon pengantin terbagi dalam dua format, yaitu: bimbingan tatap muka dan bimbingan mandiri. Keberhasilan bimbingan perkawinan pranikah bagi calon pengantin tidak dapat dilepaskan dari faktor-faktor pendukung: KUA sebagai lembaga penyelenggara, sumber dana yang dilegitimasi anggaran, calon pengantin yang menjadi peserta, narasumber yang berkualitas, materi yang tepat, serta fasilitas yang memadai. Keterbatasan dana, fasilitas, dan media pembelajaran menjadi salah satu faktor penghambat tercapainya tujuan program, yaitu upaya mewujudkan keluarga sakinah.
\end{abstract}

Kata Kunci: bimbingan perkawinan, calon pengantin, KUA, keluarga sakinah

\begin{abstract}
The purpose of this study was to find out how to implement the premarital marriage guidance program for prospective brides in KUA Cilandak District, South Jakarta City. This method of research is description with qualitative approaches. Analysis of the data used in this study is inductive logic, which uses thinking logic where syllogism is built based on specific things and leads to general conclusions. The pre-marital marriage guidance program for prospective brides held at the Office of Religious Affairs (KUA) is currently divided into two formats, namely: faceto-face guidance and independent guidance. The success of premarital marriage guidance for prospective brides can not be separated from the supporting factors: KUA as the organizing agency, the source of funds legitimized by the budget, the bride and groom participating, qualified resource persons, appropriate material, and adequate facilities. Limited funds, facilities, and learning media are one of the obstacles to the achievement of program objectives, namely efforts to realize a sakinah family.
\end{abstract}

Keywords: marriage guidance, prospective bride, KUA, sakinah family 


\section{PENDAHULUAN}

$I$ slam adalah agama yang sejalan dengan fitrah manusia. Anjuran menikah dan larangan hidup membujang (Sabiq, 2009: 12), menjadi bukti bahwa Islam begitu memahami fitrah manusia yang pada hakikatnya membutuhkan pasangan hidup (QS alNūr/24:32-33; QS al-Mā'idah/5:87). Pernikahan dipandang sebagai cara hidup yang ideal, karena ia merupakan satu-satunya cara yang halal dan diakui untuk menjalin hubungan cinta kasih antara laki-laki dan perempuan.

Tujuan agung dari pernikahan, yang diungkapkan Alquran dan diaplikasikan dalam keteladanan rumah tangga Rasulullah Saw., yaitu terwujudnya keluarga sakinah, mawaddah, warahmah, sebuah keluarga yang tenteram, harmonis, saling mencintai, saling memahami, serta penuh kasih sayang di antara mereka (QS al-Rūm/30:21).

Ketenteraman dalam rumah tangga sangat tergantung kepada pasangan suami istri. Dari sinilah kualitas kesalehan dan pengetahuan mereka tentang pernikahan menentukan, antara lain: mengerti apa yang menjadi hak dan kewajiban sebagai suami istri; bersikap saling menghargai, saling menyayangi, toleransi, mau bekerja sama, tidak egois, dan rela berkorban dalam kebaikan; mendidik, membimbing, serta mengarahkan putra-putrinya dengan memberi contoh keteladanan untuk taat pada ajaran agama (Muchdhor, 2005: 2).

Gambaran ideal keluarga sakinah yang menjadi tujuan agung dalam pernikahan, ternyata tidak serta merta dapat dirasakan oleh setiap pasangan suami istri. Fakta empiris menunjukkan, banyak ditemukan keluarga bermasalah yang diakhiri dengan perceraian, padahal perceraian merupakan perihal yang dianggap buruk menurut agama (Hadits Riwayat Abu Daud). Berdasar data Pengadilan Agama, angka perceraian pasangan suami istri terhitung cukup tinggi dari tahun ke tahun.

Dalam kurun waktu tiga tahun terakhir (2015-2017), tren perkara putusan berkekuatan hukum tetap (inkracht) perceraian di Pengadilan Agama seluruh Indonesia mengalami peningkatan. Jumlah perkara pengajuan cerai talak (suami) dan cerai gugat (istri) di 29 Pengadilan Tinggi Agama pada tahun 2015 tercatat totalnya sebanyak 394.246 yang terdiri atas cerai talak sebanyak 113.068 , cerai gugat sebanyak 281.178. Sedangkan, perkara yang diputus sebanyak 353.843 yang terdiri atas cerai talak 99.981, dan cerai gugat 253.862. Tahun 2016 tercatat 403.070 perkara yang terdiri atas cerai talak 113.968 , dan cerai gugat 289.102. Sementara, yang diputus sebanyak 365.654 yang terdiri atas cerai talak 101.928, dan cerai gugat 263.726 (https://metro.sindonews.com, diakses 5 Oktober 2017). Sedangkan tahun 2017, tercatat total perkara cerai sebanyak 415.848 yang terdiri atas cerai talak 113.987, dan cerai gugat 301.861 . Sementara, yang diputus sebanyak 374.516 perkara yang terdiri atas 100.745 cerai talak, dan 273.771 cerai gugat (https://m.hukumonline.com, diakses 18 Juni 2018).

Jumlah pertikahan di DKI Jakarta pada tahun 2017 sebanyak 82.173 pasang dengan angka perceraian sebanyak $\quad 11.551 \quad$ kasus (https://m.hukumonline.com, diakses 18 
Juni 2018). Jakarta Selatan menduduki urutan kedua terbanyak kasus perceraian setelah Jakarta Timur (Data PTA dari tahun 2014-2016). Walaupun data dari Pengadilan agama dan Badan Peradilan Agama (Badilag) Mahkamah Agung terdapat perbedaan, namun selisihnya tidak terlalu besar. Pengadilan Tinggi Agama DKI Jakarta mencatat, hingga bulan Agustus 2017, masalah perselisihan menjadi penyebab tertinggi perceraian, yaitu sebesar 2.199 kasus, ekonomi 1.255 kasus, meninggalkan pasangannya 756 kasus, dan sisanya berasal dari kasus lain (https://metro.sindonews.com, diakses 5 Oktober 2017).

Kepala Seksi I Bimbingan pada Badilag Mahkamah Agung, Hermansyah Hasyim menilai angka putusan cerai gugat selalu lebih tinggi daripada cerai talak berkisar 60-70 persen dari jumlah perkara yang masuk. Kebanyakan alasan pihak istri mengajukan gugat cerai, disebabkan ketidakharmonisan dalam kehidupan rumah tangga. Direktur Lembaga Bantuan Hukum (LBH) APIK, Venny Octarini Siregar mengakui bahwa pengajuan gugatan cerai seringkali dilakukan oleh pihak istri. Salah satu penyebabnya, perempuan dan anak kerapkali menjadi korban dari kekerasan dalam rumah tangga (KDRT) (https:// m.hukumonline.com, diakses 18 Juni 2018).

Tingginya angka perceraian menggambarkan rendahnya kualitas pasangan suami istri dalam memahami makna pernikahan. Saat ini banyak pasangan yang menikah, namun belum siap secara mental dan finansial, karena mereka tidak mempersiapkan diri ketika akan menikah, bahkan tidak pernah merencanakan perjalanan pernikahan di masa mendatang. Kondisi seperti ini mengundang keprihatinan berbagai pihak, khususnya Kementeriaan Agama, sebab keluarga merupakan salah satu fondasi terpenting dalam pembangunan sumber daya manusia. Menteri Agama Lukmam Hakim Saifuddin menilai, tingginya angka perceraian dikarenakan kurangnya perhatian dari pemerintah terkait pendidikan sistematis dan terstruktur kepada pemuda-pemudi dalam berumah tangga (https://m.republika.co.id, diakses 21 Januari 2018).

Merespon hal ini, Ditjen Bimas Islam Kementerian Agama mewujudkan program bimbingan perkawinan pranikah bagi calon pengantin sebagai upaya preventif mengatasi meningkatnya angka perceraian, yang pelaksanaannya dimulai bulan September 2017. Guna mewujudkan tertib administrasi dan akuntabilitas penyelenggaraan bimbingan perkawinan pranikah bagi calon pengantin, Ditjen Bimas Islam menerbitkan Kepdirjen Bimas Islam Nomor 379 Tahun 2018 tentang Petunjuk Pelaksanaan Bimbingan Perkawinan Pranikah Bagi Calon Pengantin. Terbitnya Kepdirjen Bimas Islam Nomor 379 Tahun 2018 mencabut Kepdirjen Bimas Islam Nomor 881 Tahun 2017.

Berdasarkan permasalahan tersebut, perlu dilakukan penelitian mengenai program bimbingan perkawinan pranikah bagi calon pengantin. Judul penelitian yang akan diangkat: "Implementasi Program Bimbingan Perkawinan Pranikah Bagi Calon Pengantin Dalam Upaya Mewujudkan Keluarga Sakinah: Studi Kasus KUA Kecamatan Cilandak Kota 
Jakarta Selatan". Penelitian ini akan mengungkap penerapan bimbingan perkawinan bagi para calon pengantin sebagai realisasi regulasi, dan upaya memberikan pemahaman komprehensif mengenai hakikat pernikahan yang output-nya terwujud keluarga sakinah.

Penelitian ini dibatasi pada program bimbingan perkawinan pranikah; objek bimbingan perkawinan adalah calon pengantin; tempat pelaksanaannya di KUA Kecamatan Cilandak Kota Jakarta Selatan; dan pelaksanaan program bimbingan perkawinan pranikah dibatasi mulai November 2018 s.d Maret 2019. Adapun rumusan masalah dalam penelitian ini adalah: "Bagaimana implementasi program bimbingan perkawinan pranikah bagi calon pengantin di KUA Kecamatan Cilandak Kota Jakarta Selatan dalam upaya mewujudkan keluarga sakinah?"

Penelitian ini bertujuan untuk mengetahui bagaimana implementasi program bimbingan perkawinan pranikah yang diselenggarakan di KUA Kecamatan Cilandak Kota Jakarta Selatan dalam upaya mewujudkan keluarga sakinah.

\section{KAJIAN TEORITIS}

\section{Konsep Perkawinan}

Kata nikah, secara etimologis berasal dari nakaḥa-yankiḥu-nikāḥan, yang berarti: "al-dhammu (berhimpun), al-jam' $u \quad$ (berkumpul), al-wat' $u$ (hubungan kelamin), al-'aqdu (perjanjian)". Secara terminologis, nikah didefinisikan :

عقد يتضمن إباحة الوط \& بلفظ النكاح و التزويج
"Akad atau perjanjian yang mengandung maksud membolehkan hubungan kelamin dengan menggunakan kata nakaha atau zawwaja" (Lajnah Pentashihan Mushaf Al-Qur'an Badan Litbang Dan Diklat Kementerian Agama Rl, 2014: 19).

Akad atau perjanjian tersebut keabsahannya sangat terkait dengan ketentuan syarat dan rukun nikah menurut syariat Islam. Para ulama telah merumuskan sekian banyak rukun dan syarat nikah yang mereka pahami dari ayat-ayat Alquran dan Alhadis. Karena itu, Taqiy al-din Abu Bakr bin Muhammad al-Husayni al-Hashaniy alDimasyqiy al-Syafi'i mendefinisikan pengertian nikah dengan batasan:

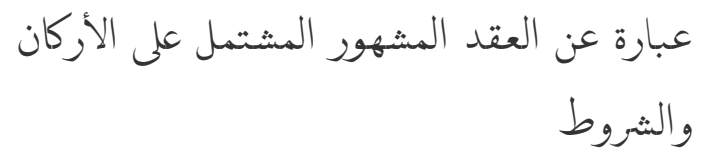

"Akad yang masyhur yang mencakup rukun-rukun dan syaratsyarat" ( Abu Bakr: 36).

Menurut Bab I, Pasal 1 UndangUndang Nomor 1 Tahun 1974 tentang Perkawinan, perkawinan adalah "ikatan lahir bathin antara seorang pria dengan seorang wanita sebagai suami istri dengan tujuan membentuk keluarga atau rumah tangga yang bahagia dan kekal berdasarkan Ketuhanan Yang Maha Esa".

Sebagai peristiwa agama yang terkait dengan perintah agama, pernikahan mempunyai tujuan: membina kehidupan keluarga bahagia dan sejahtera, hidup saling mencintai dan kasih sayang, melanjutkan dan memelihara keturunan, membentengi diri dari perbuatan maksiat dan menyalurkan naluri seksual secara halal, membina hubungan kekeluargaan dan 
mempererat silaturrahim antar keluarga (BKKBN, 2014: 2).

\section{Keluarga Sakinah}

Keluarga adalah "pasangan yang terdiri dari suami-istri dengan anakanaknya." Ini dinamakan keluarga inti. Sedangkan yang tidak hanya terdiri atas suami, istri dan anak, tetapi juga mencakup adik, kakak ipar, keponakan dan sebagainya dikenal dengan sebutan keluarga besar (Departemen Pendidikan dan Kebudayaan 1999: 471). Jadi, batasan keluarga itu minimal pasangan suami-istri, baik mempunyai anak maupun tidak. Keluarga dimaksud yaitu yang terbentuk melalui pernikahan yang sah. Maka hidup bersama seorang laki-laki dan seorang perempuan yang tidak diikat oleh pernikahan, tidak dapat dinamakan "keluarga".

Keluarga adalah 'umat kecil' yang memiliki pimpinan dan anggota, mempunyai pembagian tugas dan kerja, serta hak dan kewajiban bagi masingmasing anggotanya. Karena itu, keluarga merupakan sekolah tempat putra-putri bangsa belajar. Dari sinilah mereka mempelajari sifat-sifat mulia, seperti: kesetiaan, rahmat, dan kasih sayang. Keluarga juga adalah unit terkecil yang menjadi pendukung serta pembangkit lahirnya bangsa dan masyarakat (Shihab, 1992: 255).

Kata sakinah, secara harfiah artinya "ketenangan". Al-Raghib alAșfahaniy mengartikan al-sakīnah dengan ungkapan: "zawāl al-ru'bi", hilangnya kecemasan dan rasa takut (alAsfahaniy, 1432 H/2010 M: 178). Sementara al-Syarif 'Ali bin Muhammad al-Jurjaniy mendefinisikan al-sakinah sebagai berikut:

$$
\begin{aligned}
& \text { ما يجده القلب من الطمأنينة عند تنزل الغيب } \\
& \text { وهي نور فى القلب يسكن إلى ثـاهده ويطمئن } \\
& \text { وهو مبادى عين اليقين. (الثريف علي بن محمد } \\
& \text { الجرجاني التعريفات (صفحة : 135) }
\end{aligned}
$$

"Ketenangan yang ditemukan oleh hati ketika datang keraguan. Ketenangan tersebut merupakan cahaya yang ada dalam hati yang memberi ketenteraman kepada orang yang menyaksikannya, berdasarkan penglihatan yang meyakinkan ( 'ainu al yaqīn)" (al-Jurjaniy, 1433 H/2012 M: 135).

Dalam Alquran, kata sakinah ditemukan sebanyak enam kali, yaitu QS al-Baqarah/2:248; QS al-Tawbah/9:26, 40; QS al-Fath/48:4, 18 dan 26. Ulama tafsir menyatakan, sakinah adalah "suasana damai yang melingkupi rumah tangga pasangan suami-istri, sehingga lahirlah rasa saling mengasihi dan menyayangi di antara mereka" (Dahlan et.al., 1996: 1330).

Dari penjelasan tersebut, dirumuskan pengertian "keluarga sakinah" berdasarkan keputusan Dirjen Bimas Islam dan Penyelenggaraan Haji Nomor D/71/1999 tentang petunjuk Pelaksanaan Pembinaan Keluarga Sakinah Bab III Pasal 3 sebagai berikut: "Keluarga yang dibina atas perkawinan yang sah, mampu memenuhi hajat hidup spiritual dan material secara layak dan seimbang, diliputi suasana kasih sayang antar anggota keluarga dan lingkungannya dengan selaras, serasi, serta mampu mengamalkan, menghayati dan memperdalam nilainilai keimanan, ketakwaan dan akhlak mulia" (Badan Penasihatan Pembinaan dan Pelestarian Perkawinan (BP-4) Prov. DKI, 2012: 6). 
Selain dari kata sakinah, dalam Alquran terdapat juga kata yang relevan dan saling menguatkan, yaitu mawaddah dan rahmah. Mawaddah terambil dari akar kata "wadda-yawadduwaddan wa mawaddatan" yang artinya: "menyukai, senang, menyayangi" (Munawwir, 1884: 1651). Menurut Shihab (2007: 88), mawaddah adalah "kelapangan dada dan kekosongan jiwa dari kehendak buruk." Oleh karenanya, mawaddah bukan sekadar "cinta" yang suatu ketika bisa pudar, melainkan cinta sejati yang dilandasi kesucian hati dan kelapangan jiwa, sehingga tertutup untuk dihinggapi keburukan lahir batin yang mungkin datang dari pasangannya.

Rahmah adalah kondisi psikologis yang muncul di dalam hati akibat menyaksikan ketidakberdayaan, sehingga mendorong yang bersangkutan untuk melakukan pemberdayaan (Shihab, 1998: 47). Rahmah menghasilkan kesabaran, murah hati, tidak cemburu, tidak angkuh, tidak mencari keuntungan sendiri, tidak pemarah dan pendendam. Dengan landasan rahmah inilah, pasangan suami-istri saling menutupi kekurangan masing-masing dengan kelebihan yang ada pada diri mereka. Dalam QS al-Baqarah/2:187 disebutkan: "istri-istri adalah pakaian bagi kalian, dan kalian adalah pakaian bagi mereka."

\section{Program Bimbingan Perkawinan}

Program ialah "rancangan mengenai asas serta usaha (dalam ketatanegaraan, perekonomian, dan sebagainya) yang akan dijalankan" (https: // kbbi.web.id/program.html, diakses 13 Nopember 2018). Sedangkan bimbingan perkawinan dapat diartikan sebagai petunjuk atau penjelasan mengenai hakikat pernikahan yang mencakup: pengertian nikah dan tujuannya, serta tuntunan mewujudkan keluarga sakinah.

Program bimbingan perkawinan pranikah merupakan rancangan mengenai petunjuk dan tuntunan tentang hakikat pernikahan bagi calon pengantin yang akan membangun rumah tangga. Program bimbingan perkawinan pranikah menjadi program unggulan Direktorat Jenderal BIMAS Islam Kementerian Agama yang dituangkan dalam Kepdirjen Bimas Islam Nomor 379 Tahun 2018 tentang Petujuk Pelaksanaan Bimbingan Perkawinan Pranikah Bagi Calon Pengantin, yang meliputi: regulasi, alokasi anggaran, pengorganisasian, serta materi berikut substansi dan metode pembelajarannya.

Dalam penelitian ini, yang dimaksud dengan implementasi program bimbingan perkawinan pranikah bagi calon pengantin adalah penerapan ide dan konsep bimbingan perkawinan yang diwujudkan dalam sebuah program melalui regulasi Kepdirjen Bimas Islam Nomor 379 Tahun 2018 tentang Petujuk Pelaksanaan Bimbingan Perkawinan Pranikah Bagi Calon Pengantin sebagai program unggulan Ditjen Bimas Islam Kementerian Agama yang sasarannya "tercapai keluarga sakinah, mawaddah dan rahmah."

\section{METODE PENELITIAN}

Metode penelitian ini adalah deskripsi dengan pendekatan kualitatif. Menurut Bogdan dan Taylor (1975:5), pendekatan kualitatif "sebagai prosedur penelitian yang menghasilkan data 
deskriptif berupa kata-kata tertulis atau lisan dari orang-orang dan prilaku yang dapat diamati" (Moleong, 1991: 3). Analisis data yang digunakan dalam penelitian ini adalah logika induktif, yaitu menggunakan logika berpikir di mana silogisme dibangun berdasarkan pada hal-hal khusus atau data di lapangan dan bermuara pada kesimpulan-kesimpulan umum (Bungin, 2011: 147).

Teknik pengumpulan data yang dilakukan, antara lain:

\section{a. Observasi}

Dalam penelitian ini, observasi dilakukan dengan mengamati secara langsung pelaksanaan bimbingan perkawinan pranikah bagi calon pengantin di KUA Kecamatan Cilandak Kota Jakarta Selatan.

\section{b. Wawancara}

Data selanjutnya akan dilengkapi dengan wawancara yang dilakukan kepada: 1) calon pengantin yang mengikuti bimbingan perkawinan, 2) kepala KUA Kecamatan Cilandak, 3) narasumber, dan 4) panitia pelaksana kegiatan bimbingan perkawinan.

\section{c. Dokumentasi}

Data selanjutnya akan diperoleh dari dokumentasi berupa regulasi tentang program bimbingan perkawinan pranikah, catatan lapangan, dan rekaman pelaksanaan kegiatan bimbingan perkawinan pranikah. Kumpulan data dalam bentuk tulisan disebut dokumen, termasuk foto, rekaman suara, video, dan sebagainya. Dokumentasi digunakan untuk melengkapi data dari hasil wawancara dan pengamatan.
Penelitian ini, menggunakan 2 (dua) sumber data, yakni sumber data primer dan sumber data sekunder:

a. Sumber Data Primer

Sumber data primer dalam penelitian tentang Implementasi Program Bimbingan Perkawinan pranikah bagi calon pengantin di KUA Kecamatan Cilandak Kota Jakarta Selatan, diantaranya adalah transkrip hasil wawancara dengan Kepala KUA, calon pengantin, narasumber, panitia, serta dokumen-dokumen terkait.

\section{b. Sumber data Sekunder}

Adapun sumber data sekundernya adalah tulisan-tulisan yang relevan dengan permasalahan yang diangkat, seperti buku-buku, surat kabar, majalah, dan tulisan yang berkaitan dengan bimbingan perkawinan pranikah.

Objek yang diteliti dalam penelitian ini adalah pelaksanaan bimbingan perkawinan pranikah bagi calon pengantin di KUA Kecamatan Cilandak Kota Jakarta Selatan. Dalam penelitian ini, dilakukan pemeriksaan longitudinal yang mendalam terhadap suatu keadaan atau kejadian yang disebut sebagai kasus dengan menggunakan cara-cara yang sistematis dalam melakukan pengamatan, pengumpulan data, analisis informasi, dan pelaporan hasilnya. Yang dimaksud longitudinal di sini adalah metode penelitian yang didasarkan pada masa tertentu yang relatif lama untuk mengetahui karakter tertentu (https://artikbbi.com, diakses 24 November 2016). Studi kasus dapat menggunakan bukti baik yang bersifat kuantitatif maupun kualitatif. 


\section{TEMUAN DAN PEMBAHASAN}

\section{Temuan}

\section{a. Sejarah KUA Kecamatan Cilandak}

KUA Kecamatan Cilandak merupakan pemekaran dari KUA Kecamatan Kebayoran Lama Kota Jakarta Selatan, yang berdiri sejak tahun 1978 dengan alamat: Jl. Terogong Raya Cilandak Barat, dan berlangsung hingga tahun 1992. Pada tahun 1992 sampai sekarang, KUA Kecamatam Cilandak bertempat di Jl. KH. Muhasyim VII/90 Kelurahan Cilandak Barat, tidak jauh lokasinya dengan Kantor Kecamatan Cilandak.

KUA Kecamatan Cilandak dibangun di atas tanah kurang lebih $1000 \mathrm{M} 2$, dengan luas bangunan sekitar $400 \mathrm{M}$, yang terdiri dari dua lantai. Gedung ini diresmikan pada tanggal 21 Pebruari 1992 sebagai Gedung BP-4 dan Balai Nikah oleh Gubernur DKI Jakarta, Wiyogo Atmodarminto.

b. Letak Geografis KUA Kecamatan Cilandak

Secara geografis, KUA Kecamatan Cilandak Kota Jakarta Selatan berada di wilayah pemukiman penduduk Kelurahan Cilandak Barat. Kecamatan Cilandak terdiri dari 5 (lima) kelurahan, antara lain: Kelurahan Cilandak Barat; Kelurahan Gandaria Selatan; Kelurahan Cipete Selatan; Kelurahan Pondok Labu; dan Kelurahan Lebak Bulus. Wilayah Kecamatan Cilandak berbatasan dengan empat kecamatan, yaitu: Kecamatan Kebayoran Baru; Kecamatan Pasar Minggu; Kecamatan Kebayoran Lama; dan wilayah Kota Depok. Ini berarti, secara sosiologis KUA Kecamatan Cilandak berhadapan dengan masyarakat perkotaan yang memiliki ciri: rasional, kritis dan modern.

Kondisi tersebut memosisikan KUA Kecamatan Cilandak untuk menyesuaikan diri menjadi institusi yang siap melakukan pelayanan publik yang profesional dan akuntabel sesuai dengan fakta integritas yang telah ditandatangani oleh Kepala KUA, para Penghulu, Penyuluh Agama Islam dan JFU sebagai tolok ukur sejauh mana kualitas pelayanan publik dapat memuaskan.

c. Visi dan Misi KUA Kecamatan Cilandak

Visi dan misi menggambarkan identitas organisasi dan pemahaman terhadap arah yang ingin dituju. Untuk memberikan pelayanan kepada masyarakat agar sesuai dengan maksud pelayanan prima yaitu kepuasan pada masyarakat dari segi kuantitas dan kualitas, visi dan misi diperlukan.agar kualitas pelayanan publik terukur dan terarah. KUA Kecamatan Cilandak menetapkan visi dan misi sebagai standar pelayanan, yaitu: Visi: "Terwujudnya masyarakat Cilandak yang taat beragama, rukun, cerdas dan sejahtera lahir batin, mandiri, dan berkepribadian berlandaskan gotong royong. "

Misi:

1) Meningkatkan pelaksanaan pelayanan, pengawasan, pencatatan dan pelaporan nikah dan rujuk;

2) Meningkatkan penyusunan statistik layanan dan bimbingan masyarakat Islam;

3) Meningkatkan pengelolaan dokumentasi dan sistem 
informasi manajemen KUA Kecamatan Cilandak;

4) Meningkatkan pelayanan bimbingan keluarga sakinah;

5) Meningkatkan pelayanan bimbingan kemasjidan;

6) Meningkatkan pelayanan bimbingan hisab rukyat dan pembinaan syari'ah;

7) Meningkatkan pelayanan bimbingan dan penerangan agama Islam;

8) Meningkatkan pelayanan bimbingan zakat dan wakaf, dan

9) Meningkatkan pelaksanaan ketatausahaan dan kerumahtanggaan KUA Kecamatan Cilandak.

\section{Pembahasan}

Setiap calon pengantin yang hendak melangsungkan pernikahan diharuskan mengikuti bimbingan perkawinan pranikah yang dilaksanakan di KUA. Disebutkan dalam Bab II huruf A nomor 3 Keputusan Direktorat Jenderal Bimbingan masyarakat Islam Nomor 379 Tahun 2018 Tentang Petunjuk Pelaksanaan Bimbingan Perkawinan Pranikah Bagi Calon Pengantin, bahwa bimbingan perkawinan pranikah bagi calon pengantin diprioritaskan untuk calon pengantin yang telah mendaftar di KUA Kecamatan. Ini dimaksudkan agar mereka memahami tujuan menikah dan mengetahui hak serta kewajibannya sebagai suami-istri. Pengetahuan tentang pernikahan akan memberi energi positif bagi para calon pengantin, dan menjadi bekal untuk mewujudkan tujuan ideal, terciptanya keluarga sakinah, mawaddah, warahmah seperti yang disebutkan QS al-Rūm/30:21.

Kehidupan rumah tangga akan menjadi taman surga jika bersandar kepada ajaran Islam dan perikehidupan yang berasaskan ajaran Rasulullah Saw. Namun realitas menunjukkan, di tengah masyarakat muslim telah muncul kebiasaan yang kontradiktif dengan perilaku Rasulullah Saw. menyangkut perihal berumah tangga. Pasangan suami istri begitu mudah menempuh jalur perceraian ketika ada masalah keluarga yang sebenarnya dapat diselesaikan dengan musyawarah. Berdasarkan data dari Badilag Mahkamah Agung, sepanjang tahun 2018 ada 419.268 pasangan muslim bercerai, dan inisiatif perceraian paling banyak dari pihak perempuan, yaitu 307.778 orang. Sedangkan dari pihak laki-laki sebanyak 111.490 orang (https:// m.detk.com/news/berita/d4495627/hampir-setengah-juta-orangbercerai-di-indonesia-sepanjang-2018, diakses 3 April 2019).

Keberadaan bimbingan perkawinan pranikah sangat urgen dan dibutuhkan bagi calon pengantin, karena proses mediasi yang dilakukan di Pengadilan Agama terhadap pasangan suami istri yang sedang mengalami krisis rumah tangga, umumnya berujung pada perceraian, dan yang berhasil disatukan kembali jumlahnya lebih sedikit. Fakta tersebut semakin memberi kesan kuat dari masyarakat yang mengidentikkan Pengadilan Agama sebagai lembaga pengesah perceraian. Padahal, secara institutisional lembaga ini memiliki "peran strategis" untuk mengembalikan keutuhan rumah tangga menuju keluarga sakinah, mawaddah warahmah. Ini berarti, tugas berat 
Pengadilan Agama untuk memaksimalkan peran mediasi sebagai proses memberi solusi mendamaikan pasangan suami-istri.

Menurut Juru bicara Pengadilan Agama Jakarta Selatan, Jarkasih, bahwa perceraian yang terjadi di wilayah Jakarta Selatan rata-rata meningkat. la menjelaskan, selama tahun 2017 ada sekitar 4.000 perkara gugatan cerai ke Pengadilan Agama Jakarta Selatan. Selain faktor ekonomi dan KDRT, tumbuhnya kesadaran masyarakat terhadap hukum dalam melihat hak perempuan di dalam berumah tangga menjadi penyebab angka perceraian meningkat. Ketika terjadi hal-hal seperti KDRT atau pihak suami tidak melakukan kewajibannya kepada istri dan anakanaknya, maka pihak istri dapat mengajukan gugatan cerai (http: //poskotanews.com/2018/02/22/tahunlalu-abdee-slank-orang-ke-3-448-yanggugat- cerai- di- pa- jakarta- selatan/, diakses 22 Februari 2018).

Masalah perceraian adalah persoalan serius, sebab keutuhan rumah tangga merupakan dasar bagi keutuhan bangsa. Dengan demikian, pemerintah harus melakukan langkahlangkah strategis untuk merespon tingginya angka perceraian. Apalagi pelaksanaan pembinaan gerakan keluarga sakinah regulasinya jelas. Pada Pasal 9 Keputusan Direktur Jenderal Bimas Islam dan Penyelenggaraan Haji Nomor D/71/1999 Tentang Petunjuk Pelaksanaan Pembinaan Gerakan Keluarga sakinah disebutkan: "Kegiatan Keluarga Sakinah dilaksanakan oleh masyarakat dan Pemerintah, masyarakat sebagai pemeran utama dan Pemerintah sebagai fasilitator dan dinamisator."
Kegiatan ini dilaksanakan secara lintas sektoral yang terdiri atas Sektor Agama, Departemen Dalam Negeri dan Pemerintah Daerah, Sektor Kesehatan, Sektor Pendidikan dan Kebudayaan, BKKBN dan LSM agama dan masyarakat pada umumnya.

Dipertegas dalam Keputusan Direktorat Jenderal Bimbingan Masyarakat Islam Nomor 379 Tahun 2018 Tentang Petunjuk Pelaksanaan Bimbingan Perkawinan Bagi Calon Pengantin, bahwa membangun keluarga yang kokoh memerlukan ikhtiar sungguh-sungguh, yang dimulai dari mempersiapkan pasangan calon pengantin dan remaja usia nikah memasuki mahligai rumah tangga. Calon pengantin dan remaja usia nikah perlu mendapat pengetahuan tentang cara mewujudkan keluarga bahagia, membangun kesadaran bersama, mewujudkan keluarga sehat dan berkualitas, mengatasi berbagai konflik keluarga, memperkokoh komitmen, serta berbagai keterampilan hidup (life skills) untuk menghadapi berbagai tantangan kehidupan global yang semakin berat.

Memaksimalkan peran Kantor Urusan Agama (KUA) sebagai lembaga yang berwenang memberikan bimbingan perkawinan pranikah bagi calon pengantin adalah langkah yang diharapkan dapat mengurangi tingginya angka perceraian. Program bimbingan perkawinan pranikah bagi calon pengantin adalah wujud nyata kesungguhan Kementerian Agama dalam memastikan pembangunan bangsa melalui keharmonisan perkawinan yang ideal, mencakup penyediaan sumber daya dan anggarannya. 
Program bimbingan perkawinan (BIMWIN) pranikah bagi calon pengantin yang diselenggarakan oleh Kantor Urusan Agama (KUA) saat ini dibagi pada dua format, yaitu: bimbingan tatap muka dan bimbingan mandiri. Bimbingan tatap muka dilaksanakan selama 16 jam pelajaran (JP) sesuai dengan modul yang diterbitkan oleh Kementerian Agama, yang materinya mencakup:

a. Paparan kebijakan bimbingan perkawinan sebanyak 2 jam pelajaran;

b. Perkenalan, pengutaraan harapan, dan kontak belajar sebanyak 1 jam pelajaran;

c. Mempersiapkan keluarga sakinah sebanyak 2 jam pelajaran;

d. Membangun hubungan dalam keluarga sebanyak 3 jam pelajaran;

e. Memenuhi kebutuhan keluarga sebanyak 2 jam pelajaran;

f. Menjaga kesehatan reproduksi sebanyak 2 jam pelajaran;

g. Mempersiapkan generasi berkualitas sebanyak 2 jam pelajaran;

h. Refleksi, evaluasi, dan post tes sebanyak 2 jam pelajaran.

Seluruh proses bimbingan perkawinan pranikah selama $16 \mathrm{JP}$, wajib diampu oleh minimal dua orang narasumber terbimtek (fasilitator) yang telah mengikuti dan mendapatkan sertifikat Bimbingan Teknis (Bimtek) Fasilitator Bimbingan Perkawinan Pranikah Bagi Calon Pengantin yang diselenggarakan oleh Kementerian Agama atau lembaga lain yang telah mendapatkan izin Kementerian Agama. Materi kebijakan bimbingan perkawinan disampaikan oleh narasumber dari unsur Kantor Wilayah Kementerian
Agama Provinsi atau Kantor Kementerian Agama Kabupaten/Kota. Sedangkan, materi menjaga kesehatan reproduksi dapat disampaikan oleh narasumber dari unsur Puskesmas. Peserta bimbingan perkawinan pranikah bagi calon pengantin minimal berjumlah 25 pasang atau 50 orang. Karena itu, bila kurang dari 25 pasang/50 orang, maka pelaksanaannya dapat digabung dengan beberapa Kecamatan, dan dikoordinasikan oleh Kepala Seksi Bimas Islam Kabupaten/Kota setempat. Hal ini didasarkan pada Keputusan Direktorat Jenderal Bimbingan Masyarakat Islam Nomor 379 Tahun 2018 Tentang Petunjuk Pelaksanaan Bimbingan Perkawinan Pranikah Bagi Calon Pengantin.

Sedangkan bimbingan mandiri dilakukan jika calon pengantin tidak dapat mengikuti bimbingan tatap muka. Di sinilah peran penghulu atau penyuluh agama Islam yang telah diberi tugas memberikan konseling kepada calon pengantin secara personal. Sejak calon pengantin mendaftar ke KUA Kecamatan, pembekalan pranikah menyangkut dasar-dasar perkawinan, membangun keluarga sakinah, dan peraturan perundangan yang berhubungan dengan masalah keluarga diberikan oleh penghulu yang memeriksa dokumen persyaratan nikah. Lukman Hakim, Kepala KUA Kecamatan Cilandak Kota Jakarta Selatan mengatakan bahwa memberikan konseling tentang pernikahan kepada calon pengantin menjadi tugas penghulu, walaupun calon pengantin nanti akan mengikuti bimbingan perkawinan pranikah tatap muka (wawancara dengan Lukman Hakim, Selasa, 19 Maret 2019). 
Di KUA Kecamatan Cilandak, bimbingan perkawinan pranikah merupakan program unggulan yang sudah lama dilaksanakan, bahkan sebelum terbit Keputusan Direktorat Jenderal Bimbingan Masyarakat Islam Nomor 379 Tahun 2018 Tentang Petunjuk Pelaksanaan Bimbingan Perkawinan Pranikah Bagi Calon Pengantin, KUA Kecamatan Cilandak setiap satu bulan dua kali melaksanakan kursus calon pengantin (suscatin).

Dalam pelaksanaan suscatin, metode yang diterapkan adalah ceramah dan tanya jawab dengan aksentuasi materi: fikih munakahat, Undang-Undang Nomor 1 Tahun 1974, dan membina keluarga sakinah, mawaddah warahmah. Kegiatan pendidikan pranikah ini hanya menghadirkan narasumber dari internal KUA, yang terdiri atas Kepala KUA, Penghulu dan Penyuluh Agama Islam. Hal ini dilakukan karena tidak adanya anggaran yang menopang penyelenggaraan program tersebut. Namun demikian, Abdul Karim Hadjarati, TU KUA Kecamatan Cilandak Kota Jakarta Selatan menegaskan bahwa pendidikan pranikah harus tetap dilaksanakan betapa pun dengan keterbatasan (wawancara dengan Abdul Karim Hadjarati, TU KUA Kecamatan Cilandak, tanggal 3 Januari 2019).

Sejak terbit Keputusan Direktorat Jenderal Bimbingan Masyarakat Islam Nomor 373 Tahun 2017 Tentang Petunjuk Teknis Bimbingan Perkawinan Bagi Calon Pengantin, nama suscatin berubah menjadi Bimbingan Perkawinan (Bimwin) pranikah. KUA Kecamatan Cilandak Kota Jakarta Selatan berperan aktif melaksanakan program bimbingan perkawinan pranikah bagi calon pengantin sesuai regulasi yang telah ditetapkan sebagai implementasi amanah Kementerian Agama untuk ikut serta mengisi pembangunan nasional melalui pembinaan keluarga sakinah. Bahkan KUA Kecamatan Cilandak Kota Jakarta Selatan terpilih sebagai KUA Teladan Tingkat Provinsi DKI Jakarta pada tahun 2017, yang salah satu program unggulannya adalah "bimbingan perkawinan pranikah bagi calon pengantin" (wawancara dengan Muhammad Naufal, Penghulu KUA Kecamatan Cilandak, tanggal 3 Januari 2019).

Pada tanggal 27 dan 28 November 2018, KUA Kecamatan Cilandak mengadakan kegiatan bimbingan perkawinan pranikah bagi calon pengantin yang dihadiri oleh 30 (tiga puluh) pasang/60 (enam puluh) orang, dengan narasumber: $H$. Zulkarnain, S. Ag, M. Hum. (Kepala Sub Bagian Tata Usaha Kankemenag Kota Jakarta Selatan), H. Lukman Hakim, S.H. M.A. (Kepala KUA Kecamatan Cilandak), Mutohar Alwi, S.Ag (Fasilitator), $\mathrm{Hj}$. Endah Nina Kurniasih, M.Ag (Fasilitator), dan dr. Fitria Pratiwi (Puskesmas Kecamatan Cilandak). Materi-materi bimbingan perkawinan pranikah tersebut terdiri atas:

a. Kebijakan bimbingan perkawinan disampaikan oleh $\mathrm{H}$. Zulkarnain, S.Ag., M.Hum;

b. Perkenalan, pengutaraan harapan dan kontrak belajar dipandu oleh Hj. Endah Nina Kurniasih, M.Ag;

c. Mempersiapkan keluarga sakinah disampaikan oleh Mutohar Alwi, S.Ag.;

d. Membangun hubungan dalam keluarga disampaikan oleh Mutohar Alwi, S.Ag.i 
e. Memenuhi kebutuhan keluarga disampaikan oleh $\mathrm{H}$. Lukman Hakim, S.H, M.A;

f. Menjaga kesehatan reproduksi disampaikan oleh dr. Fitria Pratiwi;

g. Mempersiapkan generasi berkualitas disampaikan oleh $\mathrm{Hj}$. Endah Nina Kurniasih, M.Ag;

h. Refleksi, Evaluasi, dan post tes dipandu oleh panitia.

Para peserta bimbingan perkawinan pranikah umumnya merespon positif pelaksanaan program ini. Mereka mendapatkan materi dari narasumber tentang hakikat pernikahan, keluarga, dan kesehatan reproduksi yang sangat berguna sebagai bekal dalam membangun rumah tangga. Muhammad Djulfajri dan Apriliani Efendi, calon pengantin yang mengikuti bimbingan perkawinan pranikah mengatakan, bahwa pembekalan sebelum nikah bagi calon pengantin sangat penting. Karena itu, program bimbingan perkawinan pranikah harus dipertahankan, bahkan ditingkatkan kualitasnya, khusunya menyangkut narasumber dan fasilitas media pembelajaran (wawancara dengan Muhammad Djulfajri dan Apriliani Efendi, Selasa, 27 November 2018).

Pernyataan senada diungkapkan oleh Reynaldy Ibrahim dan Riza Alvianti, calon pengantin yang menjadi peserta bimbingan perkawinan pranikah. Menurut mereka, materi bimbingan perkawinan pranikah sangat baik dan bermanfaat bagi calon pengantin yang akan melangsungkan pernikahan. Namun waktu pelaksanaan selama seharian (full day) dinilai kurang efektif karena cenderung dipaksakan dan peserta kehilangan konsentrasi menyimak materi (wawancara dengan
Reynaldy Ibrahim dan Riza Alvianti, Selasa, 27 November 2018).

Berdasar pengamatan, kegiatan bimbingan perkawinan pranikah bagi calon pengantin di KUA Kecamatan Cilandak sudah berjalan dengan baik. Narasumber menyampaikan materi sesuai jadwal yang diberikan panitia, dan para peserta menyimak materi dengan cukup antusias. Tetapi metode pembelajaran yang seharusnya menggunakan pendekatan andragogi, masih tampak lebih ke pendekatan pedagogi, sehingga dialog interaktif kurang terjalin. Para narasumber terlihat dominan, padahal di Modul Bimbingan Perkawinan untuk calon pengantin yang disusun Subdit Bina Keluarga Sakinah Direktorat Bina KUA dan Keluarga Sakinah Ditjen Bimas Islam Kemenag RI, ditekankan agar para narasumber lebih berperan sebagai fasilitator.

Dengan pendekatan andragogi (orang dewasa), maka seluruh peserta bimbingan perkawinan pranikah diposisikan sebagai narasumber penting dalam proses bimbingan melalui pengetahuan dan pengalaman yang mereka miliki. Oleh karenanya, proses bimbingan bersifat partisipatoris yang melibatkan peserta sebagai subjek aktif melalui aneka kegiatan dalam bentuk curah pendapat, diskusi kelompok, diskusi berdua dengan calon suami atau istri, tanya jawab dengan narasumber ahli, bermain peran, maupun lainnya. Pendekatan ini mempunyai konsekuensi pada munculnya media bimbingan yang lebih beragam. Media bimbingan yang diperlukan antara lain: LCD, laptop, papan tulis putih, kertas flipchart, spidol besar, lakban atau perekat lainnya, kertas metaplan, spidol kecil, kertas 
HVS, dan pulpen (Rofiah, Kustini (ed.), 2017: xv-xvi).

Muthohar Alwi, salah seorang narasumber menjelaskan, keterbatasan fasilitas media pembelajaran, seperti kertas flipchart, kertas metaplan, spidol besar, lakban, gunting, dan infocus memengaruhi kondisi pembelajaran dalam bimbingan perkawinan pranikah di KUA Kecamatan Cilandak. Hal ini dibenarkan oleh Mulyanto, ketua panitia pelaksana bimbingan perkawinan pranikah dari Seksi Bimas Islam Kankemenag Kota Jakarta Selatan (wawancara dengan Muthohar Alwi dan Mulyanto, Selasa, 27 November 2018).

Menurut Lukman Hakim (Kepala KUA Kecamatan Cilandak), program bimbingan perkawinan pranikah bagi calon pengantin memiliki tujuan mulia, yaitu upaya untuk mewujudkan keluarga sakinah. Karena itu, program tersebut harus didukung secara maksimal oleh semua pihak: pemerintah, masyarakat, ulama, calon pengantin. Hal yang tidak kalah penting adalah topangan dana pelaksanaan bimbingan perkawinan pranikah bagi calon pengantin dan fasilitas yang terkait dengan pembelajaran, sebab program ini tidak akan terealisasi dengan baik tanpa dukungan dana dan fasilitas yang memadai (wawancara dengan Lukman Hakim, Selasa, 19 Maret 2019). Selama ini, anggaran pelaksanaan bimbingan perkawinan pranikah bagi calon pengantin bersumber dari Penerimaan Negara Bukan Pajak (PNBP).

$\begin{array}{crr}\text { KUA Kecamatan } & \text { Cilandak } \\ \text { menyambut } & \text { baik } & \text { untuk } \\ \text { mengimplementasikan } & \text { program }\end{array}$
bimbingan perkawinan pranikah bagi calon pengantin dengan memfasilitasi tempat pelaksanaan. Namun, yang menjadi kendala adalah pencairan anggaran bimbingan perkawinan pranikah yang sering terlambat, sehingga tidak dapat menentukan jadwal secara reguler terhadap calon pengantin yang daftar nikah. Dengan demikian, bisa terjadi ada calon pengantin yang tidak dapat mengikuti program bimbingan perkawinan pranikah, karena KUA belum bisa melaksanakan program itu. Sebab berdasarkan regulasi, seluruh kegiatan harus berbasis anggaran, sedangkan satker anggaran ada di Seksi Bimas Islam Kankemenag Kota Jakarta Selatan (wawancara dengan Lukman Hakim, Selasa, 19 Maret 2019).

Keterlambatan turunnya anggaran bimbingan perkawinan pranikah, tidak menyurutkan semangat KUA Kecamatan Cilandak untuk merealisasikan program unggulan, yakni bimbingan perkawinan pranikah. Bimbingan secara personal yang dilakukan para penghulu kepada calon pengantin yang daftar nikah, menjadi keharusan. Bahkan calon pengantin yang belum mendapatkan pembekalan pranikah dari penghulu akan dipanggil menghadap penghulu bersangkutan agar dapat menerima bimbingan perkawinan pranikah. Selain melaksanakan bimbingan personal secara reguler, KUA Kecamatan Cilandak juga bekerjasama dengan Puskesmas melakukan cek darah dan urine kepada calon pengantin. Kegiatan ini dilakukan dua kali dalam satu bulan yang tertuang dalam jadwal (wawancara dengan Siti Barokah, Bendahara KUA Kecamatan Cilandak, Selasa, 19 Maret 2019).

Ditegaskan Lukman, agar keluarga sakinah tidak hanya berhenti dalam cerita, atau pertunjukan tahunan 
melalui program pemilihan keluarga sakinah mulai dari tingkat kota, provinsi dan nasional, maka gerakan mewujudkan keluarga sakinah dengan upaya maksimal meneladani rumah tangga Rasulullah Saw., harus menjadi program prioritas KUA yang notabene sebagai lembaga pernikahan. Pembekalan pranikah melalui bimbingan perkawinan pranikah perlu ditingkatkan kualitasnya, baik yang berkaitan dengan materi, narasumber maupun fasilitas penunjang. Bahkan KUA harus mewajibkan kepada para calon pengantin yang akan menikah agar mengikuti pembekalan tersebut (wawancara dengan Lukman Hakim, Selasa, 19 Maret 2019).

Penyuluhan kepada masyarakat mengenai keluarga sakinah sangat penting, peran para penghulu dan penyuluh agama Islam diharapkan dapat maksimal dalam sosialisasi gerakan mewujudkan keluarga sakinah, yaitu sebuah gerakan yang merupakan upaya konkret masyarakat dalam rangka menanamkan, menghayati, dan mengamalkan nilai-nilai keimanan, ketakwaan dan akhlak yang mulia dalam kehidupan berkeluarga, bermasyarakat, berbangsa dan bernegara.

Keberhasilan bimbingan perkawinan pranikah dalam upaya mewujudkan keluarga sakinah, mawaddah warahmah tidak terlepas dari dukungan berbagai pihak yang terkait, yaitu Kantor Urusan Agama (KUA) sebagai penyelenggara, sumber dana yang dilegitimasi anggaran, calon pengantin, narasumber yang berkualitas, materi yang tepat sesuai sasaran yang dibutuhkan, serta fasilitas media pembelajaran. Dengan demikian, bimbingan perkawinan pranikah bagi calon pengantin tidak hanya formalitas sebagai pelengkap program.

Keterbatasan

dalam penyelenggaraan bimbingan perkawinan pranikah di Kantor Urusan Agama (KUA) memberi dampak hasil yang tidak maksimal bagi calon pengantin dalam mewujudkan keluarga sakinah. Sebagian masyarakat ada yang menganggap, mengikuti bimbingan perkawinan pranikah di KUA tidak jauh berbeda dengan mendengarkan ceramah para ustaz/ustazah di pengajian-pengajian majelis taklim. Karena itu, banyak calon pengantin yang enggan datang memenuhi undangan bimbingan perkawinan pranikah. Hal ini juga didasarkan pada alasan kesibukan bekerja, dan tidak memperoleh izin dari tempat pekerjaan.

Narasumber yang kurang berkualitas dalam penguasaan materi, ataupun metode penyampaian yang monoton, menyebabkan tidak mendapat respon positif dari peserta bimbingan perkawinan pranikah. Demikian pula materi yang tidak variatif, yakni hanya berkisar keagamaan yang didukung ayat-ayat Alquran dan hadis-hadis, tanpa didukung data-data lapangan yang realistis dan rasional. Ditambah lagi fasilitas yang tidak memadai: tempat yang kurang luas, dan media pembelajaran yang tidak lengkap, bahkan hampir semua KUA tidak menyediakan media tersebut. Ini terjadi karena tidak ada anggaran yang mendukung, padahal jika bimbingan perkawinan pranikah mendapatkan prioritas dengan dukungan penuh dari berbagai pihak/sektor, akan menjadi program yang penting dalam upaya mewujudkan keluarga sakinah, 
mawaddah warahmah bagi pasangan yang akan menikah.

\section{PENUTUP}

\section{Simpulan}

Terwujudnya keluarga sakinah mawaddah warahmah, sebuah keluarga yang tenteram, harmonis, saling mencintai, saling memahami serta penuh kasih sayang adalah tujuan agung dari pernikahan. Mewujudkan cita-cita suci ini sangat tergantung kepada pasangan suami-istri sebagai pelaku utama dalam membangun rumah tangga. Kualitas kesalehan dan pengetahuan mereka tentang hakikat makna pernikahan menjadi bekal berarti terciptanya kebahagiaan dalam keluarga.

\section{Sebelum melangsungkan} pernikahan, calon pengantin harus mempersiapkan diri, baik mental, finansial, kedewasaan, kesetabilan emosi dan kualitas spiritual untuk merencanakan perjalanan berumah tangga. Dari sinilah, keberadaan bimbingan perkawinan pranikah sangat urgen dan dibutuhkan oleh calon pasangan yang akan menikah. Ini dimaksudkan agar mereka memahami tujuan menikah serta mengetahui hak dan kewajibannya setelah menjadi suami-istri. Pengetahuan mengenai pernikahan akan menjadi bekal bagi calon pengantin untuk mewujudkan tujuan ideal, terciptanya keluarga sakinah, mawaddah warahmah.

Kantor Urusan Agama (KUA) sebagai lembaga pernikahan resmi pemerintah harus menjadi pelopor gerakan pembinaan keluarga sakinah dengan memaksimalkan program bimbingan perkawinan pranikah bagi calon pengantin, sehingga keberadaan bimbingan perkawinan pranikah berfungsi sebagai sarana efektif dalam upaya mewujudkan keluarga sakinah, mawaddah warahmah. KUA Kecamatan Cilandak Kota Jakarta Selatan telah melakukan kegiatan bimbingan perkawinan pranikah bagi calon pengantin, baik secara personal antara calon pengantin dengan penghulu, maupun melalui program bimbingan perkawinan pranikah yang diselenggarakan Bimas Islam.

Keberhasilan bimbingan perkawinan pranikah bagi calon pengantin tidak dapat dilepaskan dari faktor-faktor pendukung, seperti: KUA sebagai lembaga penyelenggara, sumber dana yang dilegitimasi anggaran, calon pengantin yang menjadi peserta, narasumber yang berkualitas, materi yang tepat, serta fasilitas yang memadai. Bila faktorfaktor pendukung tersebut tidak mendapat perhatian serius dari pihak terkait, konsekuensinya akan menjadi faktor penghambat.

Tidak maksimalnya peran KUA dalam menyelenggarakan bimbingan perkawinan pranikah, berkurangnya minat calon pengantin mengikuti bimbingan perkawinan pranikah, narasumber yang kurang berkualitas, serta fasilitas yang tidak memadai, baik tempat pelaksanaan maupun media pembelajaran, dapat menyebabkan tidak tercapainya tujuan program, yaitu upaya mewujudkan keluarga sakinah, mawaddah warahmah sesuai harapan.

\section{Rekomendasi}

Pusdiklat sebagai penyelenggara diklat harus memfasilitasi para pembina keluarga sakinah melalui diklat 
substantif keluarga sakinah dalam kecamatan dengan memberikan upaya peningkatan kualitas SDM dukungan berupa anggaran operasional narasumber bimbingan perkawinan.

Kepada pemerintah, khususnya yang pantas serta memadai.

Kementerian Agama dan Pemerintah Daerah Provinsi DKI Jakarta selaku pemegang kebijakan, agar dapat memberi perhatian serius terhadap peningkatan kualitas bimbingan perkawinan pranikah di KUA yang notabenenya sebagai ujung tombak bidang keagamaan di tingkat

Ditujukan kepada Kantor Urusan Agama (KUA), supaya berperan maksimal dalam menyelenggarakan bimbingan perkawinan pranikah bagi calon pengantin, tidak hanya berkaitan dengan pelaksanakan pencatatan administrasi nikah semata

\section{DAFTAR PUSTAKA}

Al-Qur'an al-Karim.

Al-'Ak, Khalid Abd al-Rahman. (1994). Shafwah al-Bayan Li Ma'aniy al-Qur'an al-Karim. (Cet. ke-1). Beirut: Dar al-Basyair.

BKKBN. (2014). Buku Pegangan Bagi Petugas Badan Penasihatan, Pembinaan dan Pelestarian Perkawinan: Kursus Pra Nikah Untuk Calon Pengantin, Jakarta: BKKBN.

Dahlan, Abdul Aziz, et.al. (1996). Ensiklopedi Hukum Islam, (Cet. ke-1). Jakarta: Ichtiar Baru Van Hoeve

Departemen Pendidikan dan Kebudayaan. (1999). Kamus Besar Bahasa Indonesia. (Cet. ke-10). Jakarta: Balai Pustaka.

Dokumen Kantor Urusan Agama (KUA) Kecamatan Cilandak Kota Jakarta Selatan.

Al-Jurjaniy, al-Syarif 'Ali bin Muhammad. (1433 H/2012 M). Al-Ta'rifat. (Cet. ke-1). Jakarta: Dar al-Kutub al- Islamiyah.

Kepdirjen Bimas Islam Nomor 379 Tahun 2018 tentang Petunjuk Pelaksanaan Bimbingan Perkawinan Pranikah Bagi Calon Pengantin.

Lajnah Pentashihan Mushaf Al-Qur'an Badan Litbang dan Diklat Kementerian Agama RI. (2014). Tafsir Al-Qur'an Tematik, Jilid 2. (Cet. ke-1). Jakarta: Kamil Pustaka

Moleong, Lexy J. (1991). Metodologi Penelitian Kualitatif. (Cet. ke-3). Bandung: PT. Remaja Rosdakarya.

Muchdhor, Mustofa. (2005). Buku Pintar Beruah Tangga, Suatu Penjelasan tentang Makna Pernikahan. (Cet. ke-1). Ciputat: Penerbit Kalam Pustaka.

Munawwir, Ahmad Warson. (1984). Al-Munawwir Kamus Arab-Indonesia. Yogyakarta: Pondok Pesantren "Al-Munawwir" Krapyak,

Rofiah, Nur, Kustini, ed., (2016). Modul Bimbingan Perkawinan Untuk Calon Pengantin. (Cet. ke1). Jakarta: Direktorat Bina KUA dan Keluarga Sakinah Direktorat Jenderal Bimbingan Masyarakat Islam Kementerian Agama RI 
Sabiq, Sayyid. (2009 M/1430 H). Fiqh al-Sunnah Jilid 2. (Cet. ke-21). Kairo: Dar al-Fath li al-I'lam al-'Arabiy.

Al-Shfahaniy, al-'Alamah al-Raghib. (1432 H/2010 M). Mu'jam Mufradat Alfazh al-Qur'an, Beirut: Dar al-Fikr.

Shihab, M. Quraish. (1992). Membumikan Al-Qur'an. (Cet. ke-1). Bandung: Mizan.

Shihab, M. Quraish. (2007). Pengantin Al-Qur'an: Kalung Permata buat Anak-anakku. (Cet. ke2). Jakarta: Lentera Hati.

Al-Syafi'i, Taqiy al-Din Abu Bakr bin Muhammad al-Husaini al-Hashaniy al-Dimasyqiy. Kifayat al-Akhyar, Juz 2. Beirut: Dar al-Fikr

Undang-Undang Nomor 1 Tahun 1974 tentang Perkawinan.

https://metro.sindonews.com, diakses 5 Oktober 2017.

https://m.republika.co.id, diakses 21 Januari 2018.

http://poskotanews.com/2018/02/22/tahun-lalu-abdee-slank-orang-ke-3-448-yang-gugatcerai-di-pa-jakarta-selatan/, diakses 22 Februari 2018.

https://m.hukumonline.com, diakses 18 Juni 2018.

https://kbbi.web.id/program.html., diakses 13 Nopember 2018.

https://m.detk.com/news/berita/d-4495627/hampir-setengah-juta-orang-bercerai-diindonesia-sepanjang-2018, diakses 3 April 2019. 